\title{
Overview of Language Rights in the International Criminal Law Sentencing Models
}

\author{
Dragana Spencer $^{1}$ (i)
}

Published online: 13 February 2018

(C) The Author(s) 2018. This article is an open access publication

\begin{abstract}
This paper examines the 'deep-end' of the international justice processthe incarceration of persons convicted in specially constituted international criminal tribunals and courts for gross violations of human rights, genocide, crimes against humanity and war crimes with a focus on language rights of such prisoners who are commonly serving sentences in foreign prisons. The punishment phase of the international justice process and its effects are not easily quantifiable and have been largely hidden from view. Although international criminal law asserts that equal treatment before the law requires that there be no significant disparity in punishment regimes from one sentence-enforcing country to another, comparative penology shows that there are considerable differences in the conditions of confinement and the nature of correctional services in the prison systems of different countries. This has a direct impact on post-sentence procedural and rehabilitation rights of which language rights from a key part. In this specific context, and drawing from existing literature, the paper therefore examines the extent to which enforcement practice conforms to the ideal of equal treatment espoused by the tribunals.
\end{abstract}

Keywords International justice - Enforcement of sentences · Language rights · Parity

Dragana Spencer

Dragana.Spencer@gre.ac.uk

1 School of Law and The Centre for Criminology, University of Greenwich, Old Royal Naval College, Park Row, London SE10 9LS, UK 


\section{The Transitional Justice Sentencing Context}

Modelled on the Nuremberg and Tokyo trials held after World War II, modern international criminal courts and tribunals, reflective of changing sensibilities regarding punishment, have forsworn the death penalty in favour of the custodial prison sentence. These modern institutions, and the focus of this paper, include the International Criminal Tribunal for the former Yugoslavia (ICTY), the International Criminal Tribunal for Rwanda (ICTR), the Special Court for Sierra Leone (SCSL) and the International Criminal Court (ICC). These institutions have collectively convicted over 160 persons to terms of imprisonment. However, international courts and tribunals do not operate their own prisons, relying instead on a voluntary system of negotiated sentence-enforcement agreements with individual countries to provide prison space. Sentenced persons, convicted of similar crimes, are sent to host countries where prison regimes range from high security institutions to quasitherapeutic settings. The analysis of the international criminal law sentencing rationale and its effectiveness are beyond the scope of this paper; however, it is important to highlight, for the purposes of defining the theoretical and normative parameters of language rights during internationally imposed sentences, that the existing punishment system has evolved in an ad hoc, haphazard fashion, with prisoners spread among dissimilar prison systems in a dozen European and three African countries. Although trials are conducted in public by tribunal personnel, the enforcement of sentences is outsourced to the prison service departments of countries that enter sentence-enforcement agreements with the courts. This emerging international punishment network is extensive. The ICTY has sentence enforcement agreements with seventeen European countries ${ }^{1}$ (including the ad hoc agreements with Germany) and has placed prisoners in fourteen of them. The ICTR has agreements with eight countries (three European and four African) $)^{2}$ but all but one inmate (France) are serving time in two African Countries (Mali and Benin). The SCSL has agreement with four countries ${ }^{3}$; all but one inmate (United Kingdom) are currently in Rwanda. The ICC has enforcement agreements with eleven countries ${ }^{4}$ - so far, only the DRC has housed ICC convicts.

In line with international human rights obligations, domestic, modern prison systems have, overall, adopted goals of rehabilitation and reintegration-protection and elevation of language and generally communication rights, play a key role in

\footnotetext{
1 Albania (19 Sept. 2008); Poland (18 Sept. 2008); Slovakia (7 Apr. 2008); Estonia (11 Feb. 2008); Portugal (19 Dec. 2007); Ukraine (7 Aug. 2007); Belgium (2 May 2007); United Kingdom (11 Mar. 2004); Denmark (4 June 2002); Spain (28 Mar. 2000); France (25 Feb. 2000); Sweden (23 Feb. 1999); Austria (23 July 1999); Norway (24 Apr. 1998); Finland (7 May 1997); Italy (6 Feb. 1997).

2 Senegal (22 Nov. 2010); Rwanda (4 Mar. 2008); Sweden (27 Apr. 2004); Italy (17 Mar. 2004); France (14 Mar. 2004); Swaziland (30 Aug. 2000); Benin (26 Aug. 1999); Mali (12 Feb. 1999).

3 Rwanda (18 Mar. 2009); United Kingdom (10 July 2007); Austria (16 Mar. 2005); Sweden (15 Oct. 2004).

4 Argentina (18 Apr. 2017-not in force), Sweden (26 Apr. 2017), Norway (7 July 2016), Austria (27 Oct. 2005), United Kingdom (8 Nov. 2007), Belgium (1 June 2010), Denmark (1 June 2010), Finland (1 June 2010), Serbia (20 Jan. 2011), Mali (13 Jan. 2012 - not in force) and ad hoc agreements with Democratic Republic of the Congo (DRC).
} 
this pursuit. For example, Art. 10 (3) of the International Covenant on the Civil and Political Rights 1966 provides that prison systems "shall comprise treatment of prisoners the essential aim of which shall be their reformation and rehabilitation". Principle 70 of the European Prison Rules 1987 [46], states too that "the preparation of prisoners should begin as soon as possible after reception in a penal institution" and that "social rehabilitation of prisoners, particularly maintaining and improving the relationship with their families, other persons and with the social agencies" should be facilitated and promoted. In line with this, sentence-enforcing states are often opposed to housing war criminals if their sentences are life term or exceed 30 years' imprisonment because such sentences are presumed to be both doctrinally and normatively, in conflict with rehabilitation aims. For example, under the Enforcement of Sentences Agreement with the ICTY, Portugal refuses to enforce sentences pronounced by the Tribunal exceeding the highest maximum sentence for any crime under Portuguese law [2, Art. 3]. Portugal also strongly opposed the ICC sentencing model (e.g. sentences exceeding 30 years), arguing against "demagogic tendencies aimed at imposing imprisonment-sentences that would go against the principle of humanity and frustrate the principle of rehabilitation and social reintegration of convicted persons" [18, pp. 3-4]. The right to rehabilitation of which language rights have to be part of, are also protected in some constitutions and other domestic legislation. For example, the Art. 721-1 of the French Code of Criminal Procedure 2005 provides that sentence remission can be granted to those who demonstrate "serious signs of social readjustment, especially where they successfully sit for school, university or professional examination." The Spanish Constitution 1978 also requires that imprisonment should aim at re-education and social rehabilitation of offenders (Art. 25 (2)) and the German Prison Act 1977 centres on resocialisation and rehabilitation (Ss. 2 and 3). Meanwhile, given the gravity of the crimes that international courts and tribunals deal with, these sentencing authorities primarily try to enforce principles of retribution and deterrence [41, para. 9]. It is here that language rights, as part of procedural rights and rehabilitation goals, are often not adequately safeguarded. Whilst purposes of sentencing are not detailed in ICTY, ICTR, SCSL, ICC Statutes nor the corresponding Rules of Procedure and Evidence, international criminal law jurisprudence indicates conflicting theoretical and normative approaches to sentencing. For example, in the Delalic case, ICTY Appeals Chamber held that "the main purpose of sentencing of crimes within its jurisdiction are deterrence and retribution" [27, para. 806] and that rehabilitation should not be given "undue weight" [27] but in subsequent cases, such as Obrenovic for instance, the Tribunal did indeed recognise rehabilitation as a sentencing aim [40, paras. 49 and 53]. The ICTR in the Kayishema case too considered the goal of rehabilitation as a relevant sentencing factor [30, para. 26]. In Krnojelac, the ICTY also stated that the principle of general deterrence is relevant to the determination of appropriate sentences but it must not be accorded "undue prominence" [33, para. 508]. What is more, these institutions have created an early release system after prisoners serve two thirds of their sentences. This model, which mirrors domestic parole systems, has resulted in often lenient sentences that undermine theoretical and normative purposes of the tariff period [3, p. 268]. There are numerous examples of this and the analysis of the 
penal rationale in international criminal law per se, is beyond the scope of this paper. ${ }^{5}$ However, as an illustration, the ICTY Erdemovic case can be used here; the accused, whose guilty plea to murder as a crime against humanity was given significant weight as a mitigating factor, received a 5-year sentence [29, para. 16]. It follows therefore that the enforcement of internationally imposed sentences implies rewards for demonstrated guilt and quantifiable rehabilitation, as a criterion for early release. The European Court of Human Rights confirmed in 2013 that "implicit in the right to a prospect of release...is the right to an opportunity to rehabilitate oneself" [57] and importantly that the "post-tariff review is limited to a review of the risk to society posed by the offender, as detention for the minimum period is deemed sufficient for retribution and deterrence" [55, p. 59]. Consequently, in determining the sentence-enforcing host country, international criminal courts and tribunals have an implied obligation to consider the availability and appropriateness of both therapeutic and social rehabilitation programmes [50, pp. 44, 124] and accessibility of these through an assessment of relevant language competences of sentenced persons. So far, the way in which states have been designated appear rather ad hoc and the rationale for the distribution of international prisoners across different types of institutions at a domestic level remains unclear. International courts and tribunals need only be satisfied that there is a willing state to accept a convicted person and that that state and its prison system generally comply with minimum detention international standards and guarantees. In the absence of an international prison system to rely upon, international courts periodically observe the conditions of imprisonment through monitoring arrangement by third parties, such as the Red Cross and the European Committee for the Prevention of Torture and Inhuman or Degrading Treatment or Punishment.

Obviously, it is not the function of international criminal courts to micromanage the enforcement of sentences within individual prisons nor would it be desirable for individual prisons to treat war criminals as a special category of prisoners without a compelling reason (e.g. safety). However, the nature and gravity of the crimes committed by war criminals, does require special attention. One of the reasons is that most of these convicts do not have previous criminal history. As international criminal courts focus on persons with greatest responsibility, a large proportion of those convicted are members of political ruling elites and high ranking military personnel. Their incarceration in ordinary prisons therefore not only makes them stand out from the rest of the prison population but more specifically, their rehabilitation depends on having meaningful interactions with others and engaging with rehabilitation programmes that correspond to the crimes committed, particularly because, in most cases, these criminals are significantly less likely to reoffend [5, p. 1811]. Before accepting a convicted person, some sentence-enforcing states require international courts to prove a link between the prisoner and the host country (e.g. family and/or friends) [1, Art. 2 (f)] as well as evidence of their competency to speak the local language and/or have some command of English. In the Lanzo case for example, the accused asked the ICTY if he could serve his sentence in an

\footnotetext{
$\overline{5}$ See e.g. Prosecutor v Lubanga Dyilo, Case No. ICC-01/04-01/06-2901, Trial Chamber Decision on Sentence, 10 July 2012, para. 107.
} 
English-speaking country because he had learned English during his detention in the Netherlands and wanted to advance his computer skills, also acquired during detention, for the purposes of completing a degree [35, pp. 2-3] Although convicted persons can express their views during the determination of the sentence-enforcing country, this does not extend to a right to be heard. However, in this particular case, and on an exceptional basis, the Tribunal decided that, because at the time of the decision no agreement existed with an English-speaking country, the accused would be sent to Finland to serve his sentence because here the use of English is widespread [35]. Access to rehabilitation programmes, relevant prion activities and work opportunities, is dependent on the command of the local or common language (e.g. English). Moreover, given the overall leniency of sentences imposed by international courts and the fact that majority of convicts are released after serving two thirds of the sentence, it is important that they do not spend most of the sentence in isolation (de jure or de facto) and that, at the end of it, they demonstrate significant ability to interact socially and rehabilitate to the extent that their release becomes socially and politically innocuous. In effect, they have less time to attain these goals. To this end, protection and elevation of language rights during incarceration becomes imperative.

The starting point is recognising that foreign prisoners' interpretation and translation rights, are fundamental detention rights for two main reasons: availability to adequate interpretation and translation services relates directly to, on the one hand, legal and medical assistance, access to justice, effective remedies and rehabilitation opportunities. On the other hand, linguistic isolation caused by language barriers, self-imposed or otherwise solitary confinement, or because of a lack of adequate or sufficient second language (L2) provisions, can lead to emotional and social isolation. Cumulatively, this can have an impact on the overall wellbeing of prisoners and in extreme cases amount to psychiatric damage and/or inhuman and degrading treatment.

\section{Minimum Detention Standards and the Scope of Prison Language Rights}

The enforcement of sentences imposed by international criminal courts and tribunals needs to comply with minimum and basic detention guarantees. These include Standard Minimum Rules for the Treatment of Prisoners 1957, ${ }^{6}$ the Body of Principles for the Protection of All Persons under Any Form of Detention or Imprisonment 1988, the Basic Principles for the Treatment of Prisoners 1990 and Recommendations of the International Committee of the Red Cross and the European Committee for the Prevention of Torture and Inhuman or Degrading Treatment or Punishment. Cumulatively, these provisions set out minimum protections but whilst they are generally adhered to in detention facilities of the

\footnotetext{
${ }^{6}$ Adopted by the First United Nations Congress on the Prevention of Crime and the Treatment of Offenders, and approved by the Economic and Social Council by its resolutions 663 C (XXIV), 31 July 1957 and 2076 (LXII), 13 May 1977.
} 
international courts and tribunals during pre-trial and trial proceedings, prison standards in the sentence-enforcement phase vary significantly. In fact, the Minimum Rules for the Treatment of Prisoners state that these rules "seek only...to set out what is generally accepted as being good principle and practice in the treatment of prisoners and the management of institutions" [Preliminary Observation No. 1] and that "[in] the view of the great variety of legal, social, economic and geographical conditions of the world, it is evident that not all these rules are capable of application in all places and at all times" [Preliminary Observation No. 2]. Nevertheless, Minimum Rules 1957 provide that prisons need to make every effort to "minimize any differences between prison life and life at liberty which tend to lessen the responsibility of the prisoners or the respect due to their dignity as human beings" [Rule 60 (1)].

However, all enforcement of sentence agreements between international criminal tribunals, the ICC and host states stipulate that prison/detention facilities must conform with these minimum standards and consequently there is a legitimate expectation that, in determining the enforcement jurisdiction, sentencing judges would consider the equality of treatment and look for suitability as well as parity of conditions among states that have expressed willingness to accept inmates [10, p. 3]. Consideration of specific rehabilitation programmes reflecting the crimes committed and availability of these in a language that the prisoner can understand should play a part in this process. For example, Krajisnik, an ICTY convicted war criminal whose crimes against Muslim population were not of a sexual nature [32], was transferred to a Welsh prison for sex offenders (USK, Category C) because in Full Sutton (Category A prison where he initially served his sentence), he received threats from Muslim prisoners and spent almost a year in isolation. Kovac, another ICTY convicted person, on the other hand, who did commit sexual offences (systematic and widespread enslavement and rape of Muslim women) was transferred to Norway to a prison that did not offer rehabilitation programmes for sexual offenders and where he was allowed a total of six leaves of absence [31].

Of course, international criminal courts and tribunals cannot interfere with the administration of local prisons any more than domestic courts can. For example, in R (F) the Secretary of State for Justice [2012], the UK High Court said that "it will be a rare case in which the court can be said to be entitled properly to interfere with prison authorities' exercise of professional judgment when balancing the potentially competing - and sometimes irreconcilable-right of prisoners and their transfers" [44, at. 55]. Nevertheless, as it will be shown in the Krstic case, international judges do remain ultimately responsible for the monitoring of prison conditions and for implementing any necessary remedies (e.g. transfer to another jurisdiction).

Specifically, in terms of language rights, Rule 51 of the Standard Minimum Rules for the Treatment of Prisoners stipulate that "whenever necessary, the services of an interpreter shall be used". Prisoners also have the right to informed regularly of important news and developments through provision of publications (e.g. newspapers) and other means as prescribed by the institution (Rule 39). Apart from emotional and social isolation, language problems also have significant effect on other aspects of prison life [54]. In 2014, two ICTY convicts serving sentences in Estonia alleged that their right to language had been infringed by the Vangla Prison 
because documents relating to inmates' rights and duties were given to them in the Estonian language, of which they had no command. Moreover, one of them (Martic) contended that, because of a lack of interpreting services, he had great difficulty in informing a prison officer of his need to see a doctor and explain his medical condition as well as understand, accept or reject, the relevant medical advice. He also argued that the Estonian authorities did not offer any suitable rehabilitation programmes [37, para. 5]. As a result, he submitted a letter of complaint to the ICTY, requesting transfer to another jurisdiction on the basis that his detention conditions did not meet the standards he experienced at the ICTY International Detention Facility (IDF) in Scheveningen, where he was detained during trial. In fact, this Unit "operates in line with the highest international human rights standards for treatment of detainees." 7 However, this facility is designed and operated on the presumption of innocence of those that it houses [51, Rule 5], and in many respects, exceeds the Standard Minimum Rules for the Treatment of Prisoners 1957, Basic Principles for the Treatment of Prisoners 1990, Body of Principles for the Protection of All Persons under Any Form of Detention or Imprisonment 1988 and the European Rules 1987. However, it would be unreasonable to expect that all enforcement of sentences states adhere to the same standards. The rules regarding interpretation serves at international detention units are also ample and comprehensive. The ICTY House Rules for Detainees 1995 [IT/99, Legal Assistance] provide that members of detention staff speak several languages and if the languages spoken by staff cannot be understood by a detainee, then the assistance of an interpreter can be sought at any time. In terms of legal assistance and access to justice, interpreters are also available to help detainees understanding and completing legal forms.

At a domestic level, public service interpreters (PSI), who are normally hired by police, social services, immigration authorities and prisons, face numerous challenges. Correctional settings are unique and require specialist training given the physical, emotional and security issues that high security prisons present. But, at a minimum, if not available in the institution, professional interpreters should be hired for segregation hearings, complaints, medical care and transfers. However, this is rare and often such professional services are used only when absolutely necessary. Instead, prison officers and inmates are used as interpreters and translators [17, p. 236]. This raises questions of accuracy/fidelity, confidentiality (e.g. privacy of medical records) and impartiality. For example, some inmates, although this is rare in practice, are incentivised by payments if they agree to act as ad hoc interpreters and generally act as point of contact for foreign prisoners. Whilst this may be viewed as another job for prisoners, issues of competence and conflict of interests arise here to the extent that right to competent interpretation/translation is undermined too: generally, professional and court interpreters and translators must sign a declaration regarding the given interpretation. It means that they attest to the quality and veracity of the interpretation/translation. For example, the Spanish Criminal Code 1995 provides that when interpreters (this also relates to witnesses and experts) "without substantially misconstruing the truth, alter it with hesitation,

\footnotetext{
7 www.icty.org/en/about/detention.
} 
inexactness or by silencing relevant facts or data known to him" they may be punished with a sentence of 6-9 months and be suspended from relevant public or professional employment [17, p. 242].

There are operational reasons which explain some of the difficulties on securing professional interpretation and translation services by prisons [7]. For example, in 2012 in England and Wales, one company, Applied Language Solutions (then called Capita Translation and Interpreting Ltd) was contracted by the Ministry of Justice (MoJ) to provide interpretation and translation services to courts and prisons; surveys indicate that in many instances and for many years, the service provider had been underperforming through incompetence (Applied Language Solutions framework diluted the need for specific professional accredited interpreters as well qualifications and registrations to professional bodies) [12, p. 143], delays [13, 43] and unavailability of translators for rare languages [4]. Perhaps most notable case here is that of the Nepalese Colonel Lama, whose trial before UK courts for alleged torture in 2005 during the Nepalese Civil War, pursued under domestic law and not under the jurisdiction on in international criminal court, ${ }^{8}$ was delayed in March 2015 for 6 months because a qualified, Nepalese interpreter failed to attend court. The use of Applied Language Solutions has been criticised at the time by the Inspectorate of Prisons who indicated that the over-reliance on inmates as interpreters and translators remained widespread and that access to interpreters for non-common languages was also a persistent issue. As a result, Capita TI lost the contract with the MoJ and was replaced in 2016 by a company called thebigword. As part of the deal, Capita interpreters have been transferred to thebigword. The standards and qualifications requirements have not changed and the usual problems, such as interpreters not showing up for assignments, remain. In fact, interpreters do not need to be formally accredited and relatively low hourly rates compared to corresponding professional fees, coupled with no work guarantees, means that some interpreters cannot afford to attend hearings/assignments. In a recent conversation [November 2017], an interpreter, who wishes to remain anonymous, confirmed that their Spanish to English interpretation competency consists of couple of exams with the Chartered Institute of Linguistics and a non-accredited interpretation preparation course at a further education college which provided training in vocabulary and simultaneous interpreting practicing. The training did not include any sessions on cross-cultural communication nor paralinguistics. However, if asked by judges in court proceedings whether they are qualified, they would reply 'yes'. These issues relating to MoJ interpreting services which are used by police, courts, detention centres, prison and probation service, have been largely reported in the media but what remains important to assess is whether such a system meets the necessary legal obligations under Art. 6 (3) (e) ECHR [20, p. 62], specifically the right to competent interpretation as provided for in Art. 2 (8) of the EU Directive 2010/64/EU on the right to interpretation and translation in criminal proceedings which creates certification instruments and requires interpreters to deliver 'quality sufficient to safeguard the fairness of proceedings'. Crucially, in the absence of qualitative evidence regarding the actual experience of prisoners, it is difficult to determine

$\overline{{ }^{8}}$ The case was brought under Sec. 134 (1) of the Criminal Justice Act 1988. 
what recourse foreign prisoners have against non-professional interpretation and translation services within prisons and what effective remedies exist in such cases [52, p. 41].

\section{Designation of Enforcement States}

In the early stages of sentence-enforcement agreements implementation, several practical issues were identified by professional staff from the ICTY, ICTR and SCSL at a colloquium in Arusha in 2004. Participants noted that the process of developing sentence-enforcement agreements has been difficult for the tribunals and questions were raised on how this enforcement was going to be handled, through residual mechanism once tribunals completed their work. Some sentences rendered by the ICTY, ICTR and SCSL will have to be enforced beyond the year 2035, long after all those tribunals have ceased to exist but the execution of sentences is regulated by host states and local prisons' regulatory framework (although the supervision of sentencing conditions is supervised by the Mechanism for International Criminal Tribunals (MICT), ${ }^{9}$ the international residual framework which has taken over the remaining tasks of the ICTY and ICTR).

The extent to which language rights are protected and general rehabilitation goals are pursued within this international penal regime, can vary significantly from state to state, and prison to prison. Prison monitoring and compliance regimes differ too. This is significant as linguistic isolation, as part of prison administrative isolation for example, can amount to social isolation and can, according to the United Nations' Human Rights Council [53] cause harmful psychological long term effects and be contrary to ICCPR Art.10 (3) which provides that prison systems should include necessary treatments of prisoners which aim at their reformation and social rehabilitation. It is generally accepted that hosting authorities have a duty to competently identify language skills upon admission; if a convicted person does not speak the local language or one of the common languages (e.g. English or French) then specific measures need to be taken to afford the additional support ensuring that the inmate in question can properly function in the detention facility and not become isolated [49]. For these reasons, some countries have been reluctant to accept war crimes inmates who cannot communicate in the native languages of host countries. States were also concerned about the impact the distance form their homeland would have on inmates. In one of its earliest decisions, in 1996, the ICTY acknowledged that serving sentences in foreign prisons creates "inevitable isolation" [28, para. 75], that both cultural and linguistic differences will "distinguish them (the inmates) from other detainees" and importantly, that this is particularly the case of convicted persons "who have cooperated with the Prosecutor because it is not unreasonable to assume that they will also be excluded from the very group to which they should normally belong" [28]. In a much later ruling, in 2004, the ICTY recognised and reaffirmed that serving a sentence in foreign prisons where the prisoners do not speak the relevant language, coupled with the geographical

\footnotetext{
9 U.N. SC Res. 1966 (2010).
} 
distance from their families and corresponding financial implications of family visits to foreign prisons, can amount to additional hardship and aggravation of sentences [38, para. 107]. Some host countries were in fact concerned that the distance from home would impede the maintenance of family relationships (coupled, at times, with the geographical remoteness of prisons within a state in relation to main airports and ports) and be counter to reintegration goals and some other states simply did not want the attention of foreign prison inspectors [56]. It was noted at the 2004 Arusha Colloquium that even with the assistance of the International Committee of the Red Cross, family visits were difficult and expensive to arrange (tribunals fund some family contact while subjects are detained during trial proceedings, but relinquish this responsibility to the country of imprisonment once the enforcement of sentences starts). The exception is the Kigali Central Prison which houses ICTR convicts (Law No. 47/2013) and has a population of around 3000 inmates - here all detainees have a right to visits from their families and friends once a week of up to $10 \mathrm{~min}$ [39, para. 11].

Procedurally, once a state indicates willingness to house a convicted person, the relevant tribunal presents a confidential memorandum to the president of that tribunal in which further information about the convicted person is included to assist the decision on where to transfer the prisoner. It is worth noting here that an accused does not have a right to access materials that form the basis of designation of a state decision [37, para. 3]. This information generally refers to, among other things: time already spent in detention; medical and psychological history, marital status, information about any dependants and other family relations/contact [24, p. 2], financial ability of the immediate family to arrange visits, usual place of residence, and "where applicable, linguistic skills of the convict" [16]. The SCSL Practice Direction of Designation of State for Enforcement of Sentence 2009 makes a more explicit requirement that the memorandum expressly contains information on linguistic skills of the convicted person [22, para. $4(\mathrm{v})]$. It is argued here that consideration of these skills should play a key role in the enforcement of sentence jurisdictional determination.

\section{Differences Between Prison Conditions and Standards}

Examples of disparity among host states' penal laws, relating particularly to sentence remissions based on good behaviour and rehabilitation as well as incarceration conditions are numerous and evident from, mainly, ICTY decisions on early release. Differences in incarceration models and standards and the effects of these on language rights and rehabilitation opportunities, can be seen from designation of states decisions concerning, among others, France, Italy, Belgium, Estonia, Finland and United Kingdom. For example, psychological evaluations required by the ICTY as part of reports on medical conditions of prisoners and which form part of evidence of rehabilitation, are often problematic. Due to language barriers, locally appointed psychologists examine prisoners through interpreters and other mediators. These evaluations tend to have limited/neutral value in early release determinations by the ICTY in particular, and can therefore be 
potentially procedurally and substantively detrimental to prisoners. In the Bala case, who was serving his sentence in France, psychological examination necessary for the determination of rehabilitation was difficult to perform because of the use of an interpreter so the evaluations were limited to observations of the prisoner's "attitude" during the interview and the "stricto sensu translations of the interpreter" [25, para. 19]. Bala contested the findings of the report on two grounds: firstly, that the examining psychologist was not familiar with the relevant Kosovo Albanian language and culture and secondly, that he had requested counselling but did not receive any because Albanian-speaking psychologist could not be found [25, para. 22]. Similarly, in Banovic, French authorities stated that their evidence of rehabilitation was "neutral", whilst recognising that the prisoner could not participate in relevant activities and programmes because of language barriers [26, para. 6]. In Zelenovic, the psychological investigation was conducted through an 'intermediary' [42, para. 17]. Here, the Belgian authorities concluded that since "understanding the facts depends entirely on specific socio-cultural elements" there were "many misunderstandings". 10

United Kingdom and Finland are among the sentence-enforcement host countries with the highest number of ICTY prisoners. In this context and to highlight the differences in the execution of sentences for similar crimes, examples from Finnish and British prisons housing ICTY convicts are used to outline conflicting prison conditions (liberal and high security, respectively) and to highlight the widespread use of solitary confinement in the UK for war criminal so far as they affect postconviction language rights. Whilst the reasons for housing inmates in vulnerable section units, or where these do not exist, in other form of administrative and/or solitary confinement for their own protection seem logical, it is generally accepted that these measures are not best practices and can amount to breaches of minimum detention standards and human rights. These types of segregation, which sometimes amount to spending $23 \mathrm{~h}$ a day in a cell inevitably lead to linguistic isolation which in turn can lead to serious emotional and cognitive problems [19, p. 93]. In 2010, the Inter-American Commission on Human Rights concluded that the use of confinement as a protective measure for threatened prison population is to be considered a "punitive measure" [14, p. 331]. Isolation and confinement can also be de facto situations of isolation [11, 47]; in the Lukic case, the prisoner serving his ICTY sentence in Estonia requested a transfer to The Hague and the designations of another state for the remained of his sentence on the basis that his psychological problems are growing as a direct result of his linguistic difficulties which amounted to an almost total inability to communicate with co-inmates and prison staff [36, paras. 6 and 13]. This type of isolation was exacerbated by the fact that reading materials in a language he can understand were not available and most importantly, by the impossibility of Lukic to engage with social and psychological rehabilitation programmes. It is worth noting here that in 2011, the Special Rapporteur of the Human Rights Council on Torture and Inhuman or Degrading Treatment or

\footnotetext{
${ }^{10}$ Here the Tribunal deemed the evidence of rehabilitation insufficient. For an example from Italy, see Prosecutor v Martinovic, Case No. IT-98-34-ES, Decision of the President on Early Release of Vinko Martinovic, 16 December 2011, para. 17.
} 
Punishment found specifically, that linguistic isolation in some instances can have a "devastating impact on the human spirit... and amount to torture and CID (cruel, inhumane or degrading treatment)" as a prisoner who is subject to linguistic isolation cannot have "meaningful" conversation and interaction with others [53, p. 26].

\subsection{Finland}

Finland, like Sweden and Norway, typifies liberal penal policies and incarceration regimes that are dedicated to rehabilitation and reintegration of offenders. This liberal approach to implementation of sentences is common in Scandinavian countries and is, in literature, often referred to as 'Scandinavian Exceptionalism' [23]. Finnish prisons promote rehabilitation aims through, amongst others measures, the maintaining of intimate family relationships (Prison Act 2005 (767/2005)). Finland provides 'family camp' weekends two times per year, where inmates and their families can reside together in a private cottage. Finnish inmates can also progress to an open prison setting, where they are not locked in their rooms or cells and may hold jobs in the community around the facility [15]. For example, Aleksovski and Furundzija (both sentenced by the ICTY) arrived at the same time at Kylmakoski prison in Finland. They were both Croats; Aleksovski served his full sentence there whereas Furunzdija was transferred to the open prison Kayra for the last 2 years of the sentence. Initially, war prisoners (as they were called by prisoners and staff) were placed in Section 4.0, the most secure unit of Kylmakoski as the prison staff did not know how they would adjust. They all adjusted well, and after a month were sent to Section 1.1-an open section (with doors unlocked all day). Furundzija performed maintenance work outside the facility as a cleaner. Aleksovski had a job inside the prison. Behaviour of both was excellent. Importantly, they both spoke English, and hang out with each other most of the time and kept to themselves. Aleksovski had visits from his wife and daughter; Furundzija had friends who lived in Turku. He was permitted escorted leaves to visit them. According to interviews conducted at the time, regular prisoners knew what crimes these inmates committed but did not consider them to be "real" prisoners as they were there for "political reasons". In fact, those convicted of war crimes, are often very socio-culturally different from the rest of the prison population [21, pp. 37-52]; there tend to be significant age differences and criminal backgrounds.

Landzo and Delic were both Bosnian Muslims who also served their ICTY sentences in Finland. There was frequent and considerable quarrelling between them; Delic had been Landzo's boss in 1992 during the war in Bosnia and Herzegovina had given him orders for which Landzo stood accused; Landzo testified against Delic. Prison authorities were not aware of any of this in advance. Delic, who was very respectful of prison officers promised that "everything would be ok here but not afterwards". Momir Nikolic arrived at the same prison in 2007 following again a ICTY conviction for his involvement in the extermination of Muslims at Srebrenica. Here, prison officers expected tensions ethnic and religious tensions. Instead, Delic and Nikolic hugged and Delic helped him to adjust. This was of course helped by the fact that all three inmates spoke the same languages 
(Bosnian and Serbian). Cultural adaptation was more difficult. Both Delic and Landzo found it hard to interact with female officers. For example, towards the end of his sentence, Delic tried to kiss a female prison officer. As a result, he was transferred to Turko prison whilst Landzo was transferred to Hameenlina prison because he made inappropriate remarks to a female officer. Once Delic was placed in open Section 1.1 he became very bossy with other inmates. In particular, he was very disapproving of the drug use in the prison so he accused other inmates of taking drugs and flushing them. As a result, other inmates put up one of the inmates to attacking Delic. The attacker hit Delic in the forehead with a frying pan, opening up a gash that required five stitches but the attacker go the worst of it: Delic beat him so badly that the attacker for hospitalised for a week. Delic stated that he would have killed the attacker but stopped for fear that he would never get out of prison. The attacker was paid by other inmates in commissary items and two buprenorphine tablets. Delic was transferred to Section 4.0 for his own security-he wanted to be away from the other prisoners. The incident was prosecuted in the local courts. Delic received a fine of Eur 60. He was the only ICTY convicted person with previous criminal background and had been in prison before.

A recent CPT Report into Finnish prisons and detention centres identified some good practice relating to identification and promotion of language rights of foreign nationals [48, p. 25]. For example, in the Metsala Reception Centre, an immigration facility, 19 staff were specifically employed to have direct contact with the detainees, having received training in languages, cross-cultural communication as well as psychology and human rights [48, p. 24]. Some staff were multilingual and/ or had immigrant background. It must be emphasised though that these practices had been identified mainly in immigration detention centres which house only foreign nationals and that the rationale for adopting them (e.g. resources, capacity), may not be justified in prison settings where the foreign population is relatively low, even though the Finnish Language Act 2003 under Sec. 2 (2) aims at protecting the right of everyone to good administration.

\subsection{United Kingdom}

In the UK, internationally sentenced war criminals are categorised as A category prisoners and are kept in high security facilities, along with regular domestic inmates who have committed heinous crimes. There are generally no provisions for conjugal visits with family members and prisoners held on behalf of ICTY, ICTR, SCSL and the ICC are excluded form release on temporary licence. ${ }^{11}$

Wakefield, one of the UK prisons where ICTY convicts are housed, is a facility for violent sex offenders but the prison is also used to house war criminals. An inspection report concluded that close supervision centres and the segregation unit in this prison were "very poor" with "small and stark...gated, cage-like cells" [8]. The report found that the use of translation services to make sure that foreign prisoners 'fully' [[8, p. 28] understood important documents were limited; that the translation of a booklet about prison regime in nine different languages was

\footnotetext{
11 Release on Temporary Licence (ROTL), Amendments to PSO 6300, 25 June 2012, at E (VII).
} 
unsatisfactory [8, p. 23] and that identification of foreign prisoners and corresponding support for non-English speakers, such as availability of English classes, needed to improve. However, these classes are not compulsory. There are some prison systems where English or host state language classes are compulsory, which significantly reduces language barriers from the outset. In the United States for example, the Crime Control Act 1990 requires that prisoners in federal prisons must take English as Second Language (L2) classes until they reach the proficiency level of an eighth grader on a nationally recognised achievement test. ${ }^{12}$ However, ICTY, ICTR, SCSL and ICC prisoners may not be compellable to attend such classes and this could because they are not apt at or motivated to learn a new language [19, p. 87] and there is also the possibility that communication frequency, type and level may be reduced as the prisoner/learner does not wish to appear incompetent [46, p. 77]. The relatively high age of some war criminals, particularly those convicted by the ICTY, is also a factor that may impede both the ability and the motivation to learn a new language, particularly a language from a difference family of languages than the one spoken by the prisoner. ${ }^{13}$ Moreover, coupled with the lack of relevant linguistic competence, social isolation may be caused by deliberate exclusion of war crimes prisoner by other inmates who, due to the nature and gravity of the crimes committed by those convicted by international courts and tribunals, may not wish to engage with them. For the same reason, international prisoners may not wish to engage with other prisoners because of fear of reprisals [19, p. 93]. The case of Radislav Krstic is indicative here.

In May 2010 three Muslim inmates in Wakefield prison attacked Radislav Krstic, wounding him seriously. Krstic is a Bosnian Serb Army general, whose sentence of 35 years' imprisonment for aiding and abetting genocide in Srebrenica, was confirmed by the ICTY Appeals Chamber. The three attackers were known or thought to be Islamic extremists. Prior to his transfer to Wakefield, Krstic spent 5 years in HMP Frankland within a Vulnerable Prisoner Unit (VPU) so that he would not have any contact with Muslim inmates. Wakefield does not have a dedicated VPU and so Krstic was mixing with other inmates in the Close Supervision Centre (CSC) which included a large Muslim population. He started receiving threats and was eventually attacked, when the three inmates slashed his throat with a blade. The offenders were convicted of causing GBH and were acquitted of attempted murder. Krstic then made an application to the ICTY for transfer out of jurisdiction and was finally sent sent to Poland to serve the rest of his sentence [34]. For negligence and failure to prevent both physical and psychological damage because there was sufficient evidence that an attack on Krstic was probable, Krstic was awarded damages by a local court [45, para. 130] and transferred to a prison in Poland. Whilst in the UK, Krstic was moved numerous times to different prisons. Following the attack, he was transferred to HMP Woodhill and in 2013 to HMP Long Lartin, with a supermax segregation unit, where the prison staff were instructed that no inmate should have access to Krstic. In all these facilities, Krstic was subject of linguistic isolation. He was originally housed in HMP Frankland

${ }_{12}$ Crime Control Act 1990, Public Law 101-647, Title XXIX.

${ }^{13}$ In May 2012 the average age of ICTY detainees was 59.6 (http://www.icty.org/en/about/detention). 
where he spent a considerable amount of time in the VPU to start with. In Frankland, the CPT report (December 2007) indicated that Krstic "had almost no opportunity to speak his language" and that in Wakefield there were disruptions of English language classes because of the safety risk posed by the interaction of Krstic with other inmates [6].

In the Durham Prison which houses Charles Taylor on the authority of the SCSL, a recent inspection found that around 30 foreign prisoners did not speak English and the use of professional telephone interpreting was rare and unmonitored [9, at 2.32]. Instead, prison staff relied of 'Google Translate' and there was little translation of prison literature for the non-speakers but there were in place English provisions for speakers of the other languages (ESOL) [9]. This is not surprising given the chronic underfunding of prisons. This, coupled with overcrowding problems, has rendered many basic prison services inadequate [9]. There is also judicial recognition of this reality where the UK Court of Appeal ruled that prison service's responsibilities "have to be assessed in the light of inevitable constraints imposed by what is reasonably practicable in a prison community" [9, at 3.10].

\section{Conclusion}

Within the international war crimes sentencing framework, and for reasons highlighted above, the linguistic competences of internationally convicted persons need to play an elevated and more significant role in the determination of enforcement of sentences states; international sentencing authorities should give full weight to linguistic abilities of convicted persons and recognise that their ability to function meaningfully in foreign prisons and undertake rehabilitative programmes is dependent on individual second language competence as well as availability of language support (e.g. language classes and access to competent language services, particularly where lack of lexical equivalence is apparent). On the other hand, receiving states, in determining the actual prison in which an internationally convicted person will serve the sentence, have an obligation to competently assess not only comprehension but the overall linguistic abilities and corresponding linguistic needs of prisoners at the first point of detention. The use of inmates as ad hoc interpreters and translators in detentions and prison settings is procedurally incorrect and ethically questionable where the need for the use for professional services is clear. At a minimum therefore, situations which should trigger the appointment of professional interpreters and translators within prisons relate to:

1. Determination of linguistic competence at point of detention by relevant authorities;

2. Information provision (basic information/house rules on arrival);

3. Categorisation/change of circumstances/sentence progression;

4. Transfers;

5. Health care appointments (psychological evaluations; decisions relating to involuntary hospitalisation);

6. Disciplinary hearings; 


\section{Commutation of sentences.}

In all other instances, prison staff rather than prisoners should be trained and incentivised to undertake interpretation and translation tasks, in the same way as international detention units do, employing multinational and multilingual staff who act as ad hoc interpreters for detainees for day-to-day issues. In some enforcement states there already exist legislative provisions which create positions of facilitators whose job is to assist linguistic and cultural integration of foreign prisoners. Prisoners still have a role to play and should act as people of support during the initial stages of the sentence and/or act as cultural mediators. Agreements with third sector organisations could also be explored and exploited to provide language assistance and/or relevant courses.

Open Access This article is distributed under the terms of the Creative Commons Attribution 4.0 International License (http://creativecommons.org/licenses/by/4.0/), which permits unrestricted use, distribution, and reproduction in any medium, provided you give appropriate credit to the original author(s) and the source, provide a link to the Creative Commons license, and indicate if changes were made.

\section{References}

1. Agreement between the Government of the United Kingdom of Great Britain and Northern Ireland and the International Criminal Court on the enforcement of sentences imposed by the International Criminal Court. 2007.

2. Agreement between the United Nations and the Portuguese Republic on the Enforcement of Sentences of the International Criminal Tribunal for the Former Yugoslavia. 19 Dec 2007.

3. Ambos, Kai. 2014. Treaties on international criminal law: Vol. II-The crimes and sentencing. Oxford: Oxford University Press.

4. Bowcott, Owen and Tim Midlane. 2012. Interpreters stay away from courts in protest at privatised contract. The Guardian. https://www.theguardian.com/law/2012/mar/02/interpreters-courts-protestprivatised-contract. Accessed 14 Nov 2017.

5. Choi, Jonathan H. 2014. Early release in international criminal law. The Yale Law Journal 6: 1786-1828.

6. European Committee for the Prevention of Torture (CPT), Report. 21 July 2010.

7. HM Inspectorate of Prisons. 2007. Foreign national prisoners: A follow-up report.

8. HM Chief Inspector of Prisons. 2012. Report on an unannounced full follow-up inspection of HMP Wakefield. Www.justiceinpectorates.gov.uk/prisons/wp-content/uploads/sites/4/2014/03/wakefield2012.pdf. Accessed 14 Nov 2017.

9. Her Majesty's Chief Inspector for Prisons. 2016. Report on an unannounced inspection of HMP Durham. Accessed 3-14 Oct 2016.

10. Holger-C Rohne. 2017. International jurisdiction and reconciliation-Experiences from the ICTR. https://www.mpicc.de/files/pdf1/international_jurisdiction_and_reconciliation_-_experiences_from_ the_ictr_rohne.pdf. Accessed 26 Oct 2017.

11. Honigsberg, Peter Jan. 2014. Linguistic isolation: A new human rights violation constituting torture, and cruel, inhuman and degrading treatment. Northwestern University Journal of International Human Rights 12 (1): 22-45.

12. House of Commons Justice Committee. 2013. Interpreting and translation services and Applied Language Solutions contract, Sixth Report of Session 2012-2013. 06 Feb 2013.

13. In the Matter of Capita Translation and Interpreting Limited [2015] EWFC 5. 02 Feb 2015.

14. Inter-American Commission on Human Rights. 2010. Report on immigration in the United States: Detention and due process.

15. Lahti, Raimo. 2017. Towards a more efficient, fair and humane criminal justice system: Developments of criminal policy and criminal sanctions during the last 50 years in Finland. Cogent Social 
Sciences 3 (1). www.tandfonline.com/doi/full/10.1080/23311886.2017.1303910 Accessed 19 Dec 2017.

16. Munlo, Lovemore. 2004. Enforcement of sentences in ICTR. Colloquium of Prosecutors of International Criminal Tribunals-Final Report. Arusha.

17. Martinez-Gomes, Aida. 2014. Interpreting in prison settings: An international overview. Interpreting 16 (4): 233-259.

18. Marques, Mendes. 2001. Conference on ICC Ratification in Lusophone countries, PGA International and Human Rights Programme, 19-20 February 2001, Lisbon, Portugal, Summary of Conference Proceedings.

19. Mulgrew, Roisin. 2013. Towards the development of the international penal system. Cambridge: Cambridge University Press.

20. Nicholson, Nancy Schweda. 2009. The law on language in the European Union: policy development for interpreting/translations services in criminal proceedings. The International Journal of Speech, Language and the Law 16 (1): 59-90.

21. Nicholson, Nancy Schweda. 2010. Interpreting for the international criminal tribunal for the former Yugoslavia (ICTY): Linguistic and cultural challenges. In The translator as mediator of cultures, ed. Humphrey Tonkin, and Maria Esposito Frank, 37-52. Amsterdam: John Benjamins Publishing Company.

22. Practice Direction for Designation of State for Enforcement of Sentence, 10 July 2009.

23. Pratt, John. 2008. Scandinavian Exceptionalism in an Era of Penal Excess. British Journal of Criminology 48: 119-137.

24. Prosecutor v Aleksovski, Case No. IT-95-14/1, Order Designating the State in Which Zlatko Aleksovski is to Serve His Prison Sentence. 7 July 2000.

25. Prosecutor v Bala, Case No. IT-03-66-I, Decision on Application of Haradin Bala for Sentence Remission. 15 Oct 2010.

26. Prosecutor v Banovic, Case No. IT-02-65/1, Order Issuing a Public Redacted Version of 04 September 2007 Decision on the Commutation of Predrag Banovic's Sentence. 09 Oct 2008.

27. Prosecutor v Delalic et al., Case No. IT-96-21, Judgement. 20 Feb 2001.

28. Prosecutor v Erdemovic, Case No. IT-96-22-T, Sentencing Judgment. 29 Nov. 1996.

29. Prosecutor v Erdemovic, Case No. IT-96-22-Tbis, Sentencing Judgment. 05 Mar 1998.

30. Prosecutor v Kayishema and Ruzindana, Case No. ICTR-95-1, Sentence. 21 May 1999.

31. Prosecutor v Kovac, Case No. IT-96-23\&23/1-ES, Public and Redacted Version of the 27 March 2013 Decision of President on Early Release of Radomir Kovac. 03 July 2013.

32. Prosecutor v Krajisnik, Case No. IT-00-39-ES, Order designating state in which Momcilo Krajisnik is to serve sentence. 24 Apr 2009.

33. Prosecutor v Krnojelac, Case No. IT-97-25, Judgment. 15 Mar 2002.

34. Prosecutor v Krstic, Case No. MICT-13-46-ES.1, Order Designating the State in which Radislav Krstic is to serve the remainder of his sentence (Confidential). 19 July 2013.

35. Prosecutor v Ladzo, Case No. IT-96-21-ES, Order Designating the State in Which State Esad Landzo is to Serve His Sentence. 29 Apr 2003.

36. Prosecutor v M. Lukic, Case No. MICT-13-52.ES.1, Motion for Reconsideration and Review of Sentence of Mr Lukic in Estonia and transfer to The Hague. 27 Jan 2016.

37. Prosecutor v Martic, Case No. IT-95-11-ES, Decision on Milan Martic Request for Reconsideration of Order Designating State in Which He is to Serve His Sentence. 05 Mar. 2009.

38. Prosecutor v Mrdja, Case No. IT-02-59-S. 31 Mar 2004.

39. Prosecutor v Munyagishari, Case No. MICT-12-20, Second Monitoring Report for November 2014. 17 Dec. 2014.

40. Prosecutor v Obrenovic, Case No. IT-02-60/2-5, Sentencing Judgment. 10 Dec 2003.

41. Prosecutor v Tadic, Case No. IT-94-1, Sentencing Judgment. 11 Nov 1999.

42. Prosecutor v Zelenovic, Case No. IT-96-23/2-ES, Decision of President on Early Release of Dragan Zelenovic. 30 Nov 2012.

43. R v Applied Language Solutions Ltd [2013] EWCA Crim 326.

44. R (F) the Secretary of State for Justice [2012] EWHC 2689 (Admin).

45. Radislav Krstic and (1) Ministry of Justice and (2) Secretary of State for Justice, Judgment, Central London County Court, Claim No. 2YJ09540. 06 Oct 2015.

46. Ramirez, Linda Friedman (ed.). 2010. Cultural issues in criminal defence. Huntington: Juris Publishing. 
47. Recommendation No. R (87) 3, Council of Ministers to Member States on European Prison Rules 1987.

48. Report to the Finnish Government on the visit to Finland carried by the European Committee for the Prevention of Torture and Inhuman or Degrading Treatment or Punishment (CPT). 2015. CPT/Inf (2015) 25.

49. Report to the Government of the United Kingdom on the visit to the United Kingdom carried out by the European Committee for the Prevention of Torture and Inhuman and Degrading Treatment or Punishment (CPT). 2017. CPT/Inf (2017) 9.

50. Robinson, Gwen, and Iain Crow. 2009. Offender rehabilitation: Theory, research and practice. London: Sage Publishing.

51. Rules Concerning the Detention of Persons awaiting Trial or Appeal before the Tribunal or otherwise Detained on the Authority of the Tribunal, Rev. 10. 15 Nov 2016.

52. Silverstri, Ariana. 2013. Prison conditions in the United Kingdom-European Prison Observatory: Detention Conditions in the European Union, pp. 1-59.

53. Special Rapporteur of the Human Rights Council on torture and other cruel, inhuman or degrading treatment or punishment. 2011. Interim Report of the Special Rapporteur of the Human Rights Council on Torture and Other Cruel, Inhuman or Degrading Treatment or Punishment. 70 U.N. Doc. A/66/268.

54. Van Kalmthout, A., et al. (eds.). 2007. Foreigners in European prisons. Nijmegen: Wolf Legal Publishers.

55. Van Zyl Smit, Dirk, Pete Weatherby, and Simon Creighton. 2014. Whole life sentences and the tide of European human rights jurisprudence: What is to be done? Human Rights Law Review 14 (1): 59-84.

56. Vermaulen, Gert, and Eveline De Wree. 2014. Offender reintegration as a component of international execution of sentences at the level of international tribunals and courts. Antwerp: MakluPublishers.

57. Vinter and Others v United Kingdom, Application Nos. 66069/09, 3896/10 and 130/10, Merits. 09 July 2013. 